\title{
Breeding system evolution in Primula vulgaris and the role of reproductive assurance
}

\author{
J. G. Piper, B. Charlesworth† \\ and D. Charlesworth $\dagger$
}

School of Biological Sciences, University of Sussex, Falmer, Brighton BN1 9QG.

Reproductive assurance in the absence of pollinators has frequently been discussed as a major factor in the evolution of self-fertilisation. An attempt was made here to assess the importance of this factor in the evolution of the self-fertile homostyle morph in Somerset populations of $\boldsymbol{P}$. vulgaris by a comparison of the relative fertilities of homostyle and outcrossing (pin and thrum) morphs. Several indices of fertility indicated that at some populations in some seasons homostyles were significantly more seed fertile than the pins and thrums. This trend in relative fertility made it clear that reproductive assurance could have had a profound effect on the evolution of self-fertilisation in this species.

The proximate cause of variation in relative fertility was shown to be variation in pollinator service due to differences in rainfall between seasons. Factors such as sexual resource reallocation, reproductive economy, and inbreeding depression were not shown to have a significant effect on the relative fertility of the self-fertilising and outcrossing morphs.

\section{INTRODUCTION}

Populations of Primula vulgaris typically exhibit a floral dimorphism known as distyly (Darwin, $1876 ; 1877)$. Approximately half the individuals in distyled species have long styles and low anthers (pins), the others having a short style and high anthers (thrums). Both morphs are self-incompatible, and interfertile; thus distyly enforces outcrossing (Cahalan and Gliddon, 1985). The loci responsible for the dimorphism are rightly linked, and are inherited as a supergene (Bateson and Gregory, 1905); recombination within the supergene occurs infrequently (Ernst, 1936a; $b$ ). Usually there are two supergene "alleles", the thrum form (dominant), and the pin form (recessive). Thrums are heterozygous at the supergene loci, and pins are homozygous, so the progeny of compatible matings are pins and thrums in a one to one ratio.

Despite low rates of recombination within the supergene, a recombinant homostyle form has become established in Somerset populations of $P$.

$\dagger$ Current address and the one to which reprint requests should be sent: Department of Biology, University of Chicago, 1103 E57th Street, Chicago, Illinois 60637, U.S.A. vulgaris over a wide range of frequencies, (Crosby, 1949; Curtis and Curtis, 1985). It has achieved a maximum frequency of about 80 per cent, and appears to eliminate thrums prior to pins (although an exceptional population has been located consisting solely of homostyles (Curtis and Curtis, 1985)). The long homostyle (homostyle hereafter) morph, which has a pin type gynoecium and a thrum type androecium, is self-fertile, and has been demonstrated to be largely self-fertilising in natural populations (Crosby, 1959; Piper et al., 1984; Curtis et al., submitted for publication). Because homostyles have thrum type anthers, they compete with thrums for access to pin ovules, and although in theory thrums can fertilise homostyles, this occurs infrequently because of the high rates of self-fertilisation experienced by the homostyles. The appearance of this morph in populations of this normally outcrossing species has been regarded as an example of the evolution of selffertilisation (Fisher, 1941; Crosby, 1949; Dowrick, 1956; Charlesworth and Charlesworth, 1979; Piper et al., 1984, Curtis et al., submitted for publication), although not without some controversy (Bodmer, 1960; 1984; Crosby, 1960).

A factor that has frequently been proposed as playing a major role in the evolution of 
self-fertilisation is reproductive assurance (reviewed by Jain (1976) and Lloyd (1980)). In environments where the transfer of pollen between plants is restricted, due to poor pollinator service in inhospitable environments (Hagerup, 1932; 1951; Baker, 1959; Ghiselin, 1969; 1974), selfincompatible or unisexual individuals cannot produce large seed crops. In contrast, autogamous individuals can, provided that inbreeding depression is not severe enough to induce high rates of progeny loss (Charlesworth and Charlesworth, 1979; Lloyd, 1979; 1980).

In 1984 (Piper et al., 1984) we presented an outline of two factors involved in the evolution of self-fertilisation (the rate of self-fertilisation, and the relative fertility of the self-fertile form), in Somerset populations of $P$. vulgaris. We now propose to describe our results on relative fertility more thoroughly, and present additional data from more populations, our primary aim being to explore further the role of reproductive assurance in the evolution of self-fertilisation. This was investigated by an assessment of the reproductive success of self-fertilising (homostyle) and outcrossing (pin and thrum) morphs in Somerset populations of $P$. vulgaris.

Factors other than reproductive assurance can affect the relative fertility of co-occurring, selffertilising and outcrossing morphs of the same species. These factors include: differences in sexual resource allocation (Charlesworth and Charlesworth, 1981); differences in flower production (Baker, 1965; Primack, 1978; Colosi and Cavers, 1984); and the expression of inbreeding depression via seed abortion (Brink and Cooper, 1947; Rowlands, 1960; Link, 1961; Sayers and Murphy, 1966; Sorenson, 1969; Koski, 1971; Franklin, 1972; James, 1979) or reduced seed mass (Darwin, 1876; Schaal and Leverich, 1984). An attempt was made to establish the impact of these factors on the relative fertility of pin, thrum, and homostyle morphs of $P$. vulgaris, in addition to any effects of reproductive assurance. Differential grazing of the flowers and capsules could affect the fecundity of the various morphs. This will be the subject of a forthcoming publication.

\section{MATERIALS AND METHODS}

\section{(i) Population censusing}

Primula vulgaris. Huds is a perennial herbaceous species native to, and distributed throughout, the British Isles. It has a basal rosette of leaves, and produces yellow flowers in a successional fashion from February to May. Occasionally, in mild years, a second flush of flowering occurs in late autumn (Clapham et al. 1962).

To obtain estimates of the fertility of selffertilising and outcrossing morphs of $P$. vulgaris, population censusing was performed in Somerset populations, some with and some without homostyles, throughout the flowering seasons of 1982 and 1983. In 1984, a less rigorous attempt to assess the relative fertility of self-fertilising and outcrossing morphs was undertaken. Different numbers of populations were censussed in each season, so that 13 populations were studied in all over a 3 year period, several more than once.

In 1982, five populations (four with homostyles) were visited at four to eleven day intervals from mid March to the end of May. On each visit, the number of flowers, seed capsules, and the number of flowers that failed to set seed were recorded for each plant in a sample of the morphs represented at the populations studied. This permitted the establishment of the total numbers of flowers and seed capsules produced by the three morphs during the flowering season. After flowering several naturally pollinated seed capsules per plant were collected, and the number of seeds each contained was determined. As seed capsule production and the mean numbers of seeds per capsule were known for all individuals studied, total seed output per individual could be estimated.

In 1983, a similar protocol to that followed in 1982 was adopted, except that ten populations (seven with homostyles) were censussed at 11 to 17-day intervals from mid March to the end of May. In addition, individual flowers (up to six per plant) were labelled on all plants at the start, in the middle, and towards the end of the flowering season, and their fates (i.e., whether they did or did not produce seed capsules) recorded. When flower production among morphs does not differ, estimates of seed capsule production obtained by this method are equivalent to estimates of seed capsule production on a per plant basis, though formally they represent estimates of seed capsule production per flower. Once again, estimates of whole plant fertility for all the morphs were obtained.

In 1984, six populations (three with homostyles) were studied. No attempt was made to establish the floral output or total seed production for each individual. Instead, flowers were labelled at the peak of the flowering season, and those that had set seed by the end of the season were collected, and the number of seeds contained in each capsule was established. 
A map showing the locations of the populations, and frequencies of the morphs is presented in fig. 1 .

\section{(ii) Reproductive assurance}

To determine if differences in pollen flow between individuals could account for any differences in fertility among outcrossing and self-fertilising morphs of $P$. vulgaris, one flower per pin and thrum plant at all the populations studied in all seasons was pollinated by hand with compatible pollen. This was not done with homostyles; they receive sufficient pollen to achieve good seed set (Piper et al., 1984). The artificially pollinated capsules were collected after flowering, and the number of seeds each contained was determined.

\section{(iii) Sexual resource allocation}

Thrum type anthers (i.e., those of thrums and homostyles) contain larger and less numerous pollen grains than pin type anthers; investment made in male function by outcrossing and self-fertilising morphs of $P$. vulgaris was therefore assessed by comparing pollen grain production per anther by thrums and homostyles. Two populations were chosen, one with a low homostyle frequency (Wanstrow 1), and one with a high homostyle frequency (Postlebury). Undehisced anthers from 20 different individuals were collected from homostyles at both populations, and from thrums at Wanstrow 1. They were bisected, air dried, and crushed on a glass slide. The pollen grains were then spread over the slide surface and counted under a compound microscope. To assess investment made by outcrossing and self-fertilising morphs of $P$. vulgaris in female function, the ovule number per ovary for 30 individuals of each morph at the populations studied in 1982 was determined. Relative seed numbers and seed weights for the three morphs were also estimated.

\section{(iv) Inbreeding depression}

To seek evidence for inbreeding depression in the progeny of homostyles in terms of abortion or reduced seed mass, the numbers of seeds in

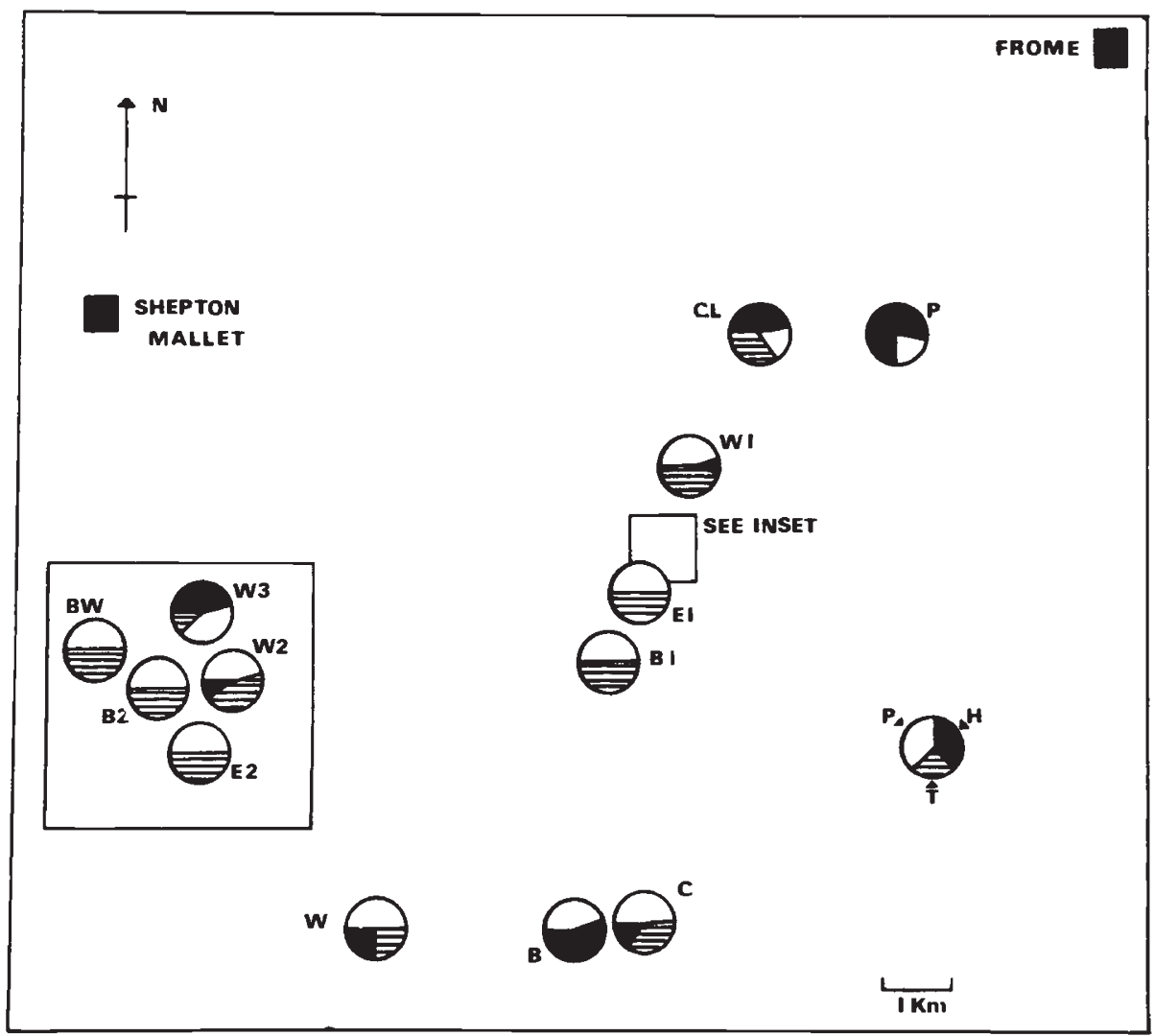

Figure 1 Map showing location and morph frequencies of the populations of Primula vulgaris studied. P: Postlebury, CL: Cloford, W1: Wanstrow 1, BW: Batcombe Wood, W3: Wanstrow 3, B2: Batcombe 2, E2: Eastcombe 2, E1: Eastcombe 1, B1: Batcombe 1, W: Wyke Champflower, B: Bruton, C: Cogley. 
capsules of naturally pollinated flowers of outcrossing and self-fertilising morphs were counted, and known numbers of seeds of each morph were weighed on a Satorius model 1201 MP2 analytical top pan balance to obtain a value of mean seed mass for each morph.

\section{(v) Statistical analysis}

The mean total number of flowers produced in a season, the mean number of seeds produced by flowers that were naturally or artificially pollinated, and the mean seed weights, for each morph in any one population were compared by one way analysis of variance, as were the mean numbers of pollen grains per anther, and the mean numbers of ovules per ovary for each population. Non orthogonal comparisons among means were made using the Tukey-Kramer method (Sokal and Rohlf, 1981). The proportions of labelled flowers per morph that produced seed capsules (in 1983 and 1984) were compared at each population by $\mathrm{G}$ tests of independence (Sokal and Rohlf, 1981.)

\section{RESULTS}

\section{(i) Flower and seed capsule production}

Population censusing techniques employed in 1982 and 1983 enabled the calculation of the mean total number of flowers, and the mean number of seed capsules produced by each morph represented at the populations studied. These data are presented in tables 1 and 2 . The results of the flower labelling technique, adopted in 1983 and 1984 in order to assess the fates of individual flowers, are presented in tables 2 and 3 .

Examination of the data presented in tables 1 and 2 suggests that there was not a consistent trend in terms of the number of flowers produced in a season by the three morphs of $P$. vulgaris. At Wanstrow 1 in 1982, thrums produced significantly more flowers than homostyles, and at Wanstrow 2 and Bruton in 1983 homostyles produced significantly fewer flowers than the outcrossing morphs in these populations. At all the other populations studied in 1982 and 1983 (except Cloford in 1982, where homostyles produced significantly more flowers than pins and thrums) significant differences among morphs were not observed. Clearly there is not an overall tendency for homostyles to produce fewer flowers than pins and thrums.
In contrast to flower production, variation in seed capsule production between the selffertilising and outcrossing morphs over the three years of study was very obvious. The seed capsule production data in table 1 reveals that there was spatial variation in this index of fertility in 1982. At the two high frequency homostyle populations (Cloford and Postlebury), homostyles produced significantly more seed capsules than the outcrossing morphs, but at the low frequency homostyle populations (Wanstrow 1 and Wyke) significant differences were not observed.

A comparison of the seed capsule production data in tables 2 and 3 illustrates that there was temporal variation as well as spatial variation in seed capsule production of pins and thrums relative to homostyles. In 1983 there was a tendency for homostyles to produce more seed capsules per plant than pins and thrums. At four of the seven populations studied where homostyles and the outcrossing morphs co-occurred (Cogley, Wyke, Wanstrow 3, and Cloford), homostyles produced significantly more seed capsules per plant, an observation confirmed by the censusing and the flower labelling data. At two of the remaining three populations (Wanstrow 2, and Bruton) the differences were not significant. However, at these two poulations the outcrossing morphs produced significantly more flowers per plant, thus homostyles did produce more seed capsules per flower, if not more seed capsules per plant. Therefore, in 1983 homostyles tended to experience better seed capsule production than pins and thrums.

In 1984 this trend was not observed; at the three populations where homostyles were represented (Cogley, Bruton, and Postlebury) seed capsule production among morphs did not differ. These observations suggest that there were fluctuations in pollinator services from year to year, and this theme is considered further below.

Analysis of seed capsule production by the three morphs in the populations studied in 1982 and 1983 revealed another trend. The flower labelling data presented in table 2 show that in all populations (except Wyke and Cloford) where pins, thrums and homostyles were represented, pins matured more seed capsules per flower than thrums. Population censusing in 1982 (table 1) also showed this trend at Cloford. (It is probable that this trend was not observed at Cloford in 1983 because of extremely high levels of predation. (Piper, 1984).) That pin seed capsule production exceeds that of thrums where homostyles are present suggests one cause of the elimination of thrums prior to pins when homostyles are increasing in frequencv. 
Table 1 Fertility components, with their standard errors for pins, thrums, and homostyles at the populations studied in 1982

\begin{tabular}{|c|c|c|c|c|c|c|c|}
\hline \multirow[b]{2}{*}{ Population } & \multirow[b]{2}{*}{ Morph } & \multirow[b]{2}{*}{$\begin{array}{l}\text { Flowers } \\
\text { per plant }\end{array}$} & \multirow[b]{2}{*}{$\begin{array}{l}\text { Seed capsules } \\
\text { per plant }\end{array}$} & \multicolumn{2}{|c|}{ Mean seeds per capsule } & \multirow[b]{2}{*}{$\begin{array}{l}\text { Seeds per } \\
\text { plant }\end{array}$} & \multirow[b]{2}{*}{$\begin{array}{l}\text { Number } \\
\text { of plants }\end{array}$} \\
\hline & & & & $\begin{array}{l}\text { Natural } \\
\text { pollination }\end{array}$ & $\begin{array}{l}\text { Artificial } \\
\text { pollination }\end{array}$ & & \\
\hline \multirow[t]{2}{*}{ Batcombe 1} & $\mathbf{P}$ & $17 \cdot 8 \pm 1 \cdot 3$ & $9 \cdot 5 \pm 0.9$ & $49 \cdot 2 \pm 3 \cdot 2$ & $47 \cdot 9 \pm 3 \cdot 1$ & $480 \pm 60$ & 17 \\
\hline & $\mathrm{T}$ & $17 \cdot 4 \pm 2 \cdot 3$ & $11 \cdot 3 \pm 1 \cdot 5$ & $43 \cdot 2 \pm 2 \cdot 6$ & $44 \cdot 1 \pm 2 \cdot 9$ & $475 \pm 50$ & 20 \\
\hline Wanstrow 1 & $\mathrm{P}$ & $36 \cdot 7 \pm 3 \cdot 3$ & $14 \cdot 8 \pm 2 \cdot 6$ & $45 \cdot 4 \pm 3 \cdot 6$ & $44 \cdot 9 \pm 4 \cdot 1$ & $647 \pm 122$ & 17 \\
\hline \multirow{3}{*}{ Wyke } & $\mathrm{P}$ & $7 \cdot 6 \pm 0 \cdot 8$ & $4 \cdot 5 \pm 0 \cdot 5$ & $42 \cdot 2 \pm 1 \cdot 8$ & $56 \cdot 0 \pm 4 \cdot 7 \ddagger$ & $213 \pm 21$ & 24 \\
\hline & $\mathrm{T}$ & $11 \cdot 2 \pm 1 \cdot 4$ & $4.9 \pm 0.6$ & $44 \cdot 1 \pm 2 \cdot 3$ & $55 \cdot 7 \pm 3 \cdot 9$ & $238 \pm 33$ & 26 \\
\hline & $\mathrm{H}$ & $7 \cdot 4 \pm 0.6$ & $5 \cdot 0 \pm 0 \cdot 5$ & $52 \cdot 3 \pm 2 \cdot 4^{*}$ & - & $255 \pm 29$ & 27 \\
\hline \multirow[t]{3}{*}{ Cloford } & $\mathrm{P}$ & $12 \cdot 9 \pm 1 \cdot 3$ & $7 \cdot 9 \pm 1 \cdot 1^{P}$ & $35 \cdot 6 \pm 4 \cdot 1$ & $42 \cdot 7 \pm 5 \cdot 3 \dagger$ & $316 \pm 58^{P}$ & 28 \\
\hline & $\mathrm{T}$ & $12 \cdot 8 \pm 0 \cdot 9$ & $4 \cdot 6 \pm 0 \cdot 6$ & $23 \cdot 2 \pm 3 \cdot 4$ & $42 \cdot 1 \pm 5 \cdot 3 \dagger$ & $143 \pm 21$ & 15 \\
\hline & $\mathrm{H}$ & $15 \cdot 1 \pm 1 \cdot 0^{*}$ & $11 \cdot 6 \pm 0 \cdot 9^{*}$ & $45 \cdot 0 \pm 2 \cdot 0^{* *}$ & - & $513 \pm 49^{* *}$ & 38 \\
\hline
\end{tabular}

${ }^{T}$ For this character, thrums greater than homostyles $(p<0.05)$.

${ }^{P}$ For this character, pins greater than thrums $(p<0.05)$.

* For this character, homostyles greater than pins and thrums, $p<0.05$, and $* * p<0.01$.

$\dagger$ Artificially pollinated capsules more seed fertile than corresponding naturally pollinated capsules $(p<0.05$, or $\ddagger p<0.01)$.

Table 2 Components of fertility for pins, thrums, and homostyles at the populations studied in 1983. Values in the first five columns are presented with their standard errors. Numbers in brackets refer to the number of flowers that were labelled at each population.

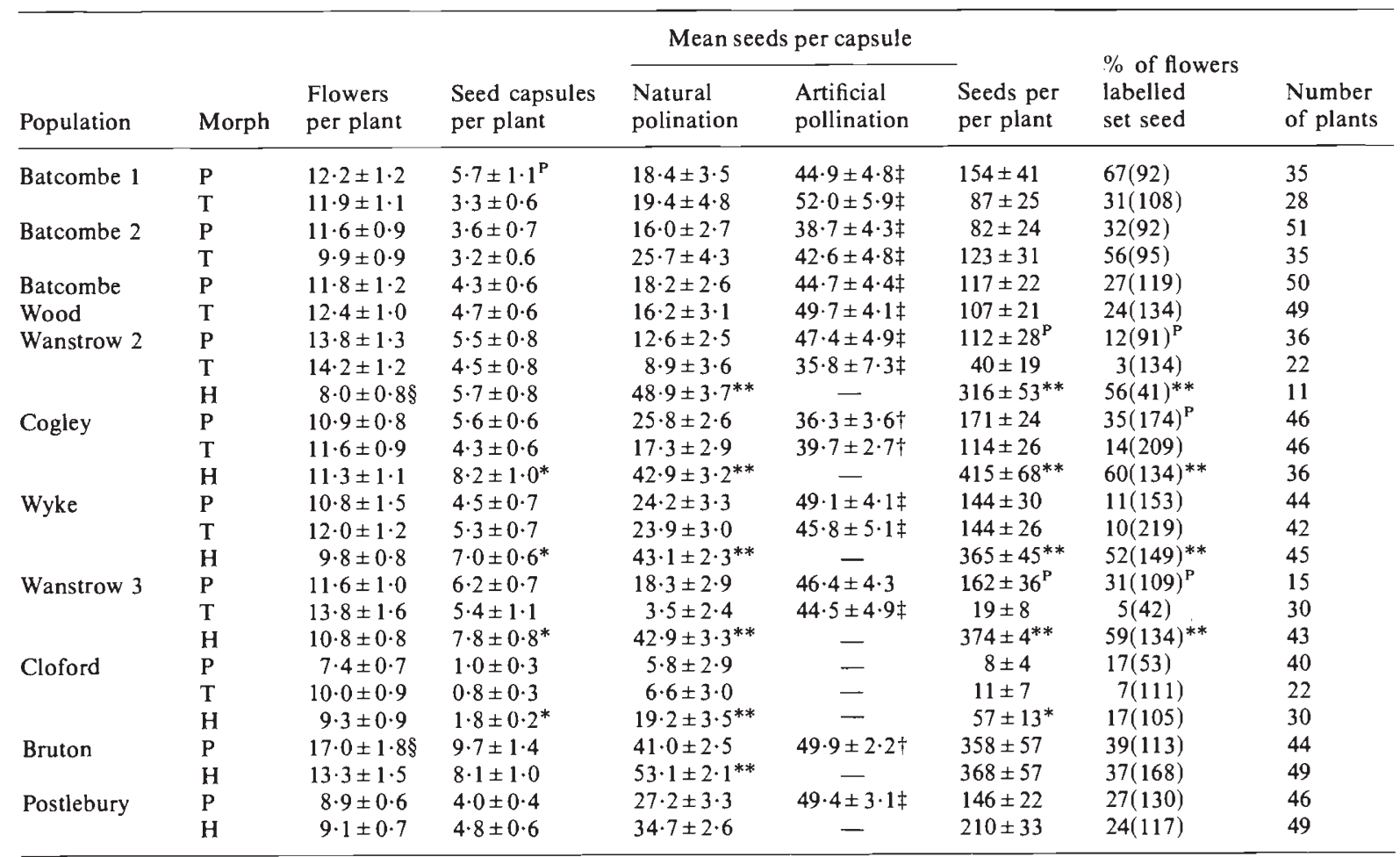

$\S$ For this character, homostyles less than pins and thrums $(p<0.05)$.

* For this character, homostyles greater than pins and thrums, $p<0.05$, and $* * p<0.01$.

${ }^{P}$ For this character, pins greater than thrums $(p<0.05)$.

$\dagger$ Artificially pollinated capsules more seed fertile than corresponding naturally pollinated capsules $(p<0 \cdot 05$, or $\ddagger p<0.01)$. 
Table 3 Fertility components of pins, thrums, and homostyles at the populations studied in 1984. Values in the first two columns are presented with their standard errors

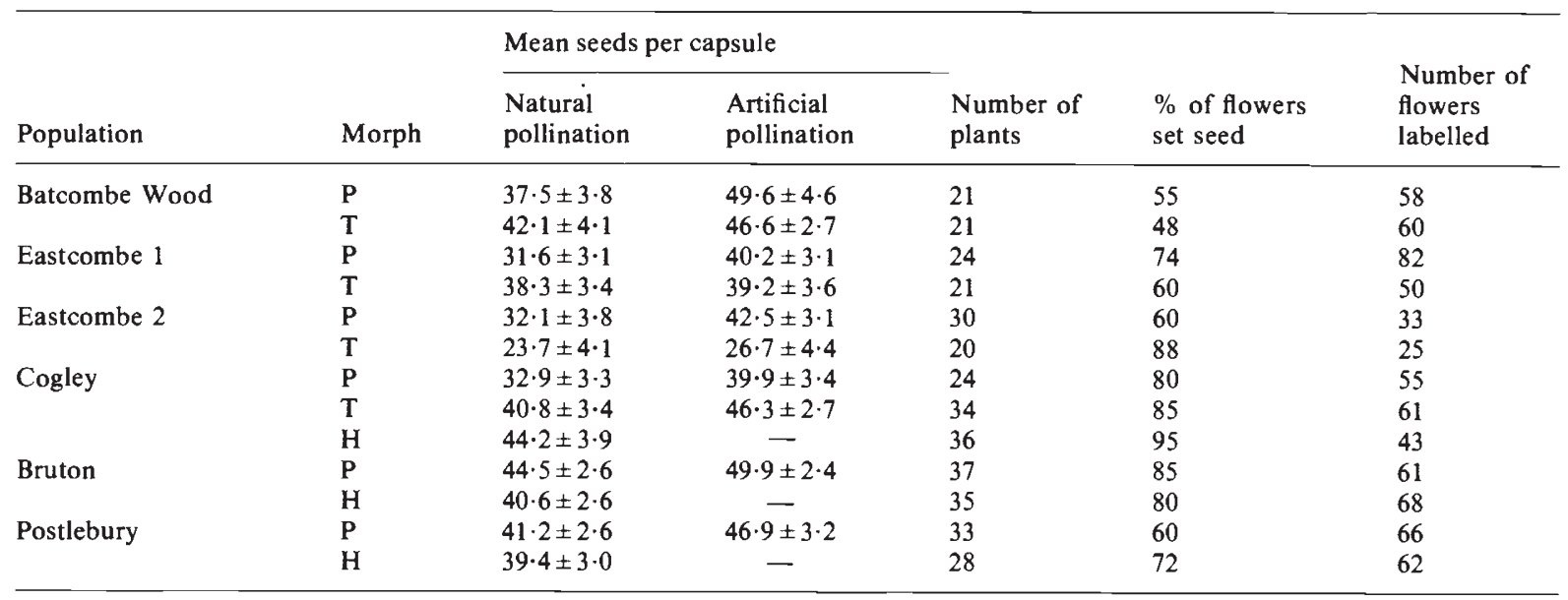

\section{(ii) Seeds per capsule with natural and artificial pollination}

Tables 1 to 3 also present the mean number of seeds per capsule for naturally and artificially pollinated flowers of the morphs in the populations studied in 1982, 1983, and 1984 respectively. These data permit an assessment of the importance of pollinator availability to the fertility of pins and thrums, even in homostyleless populations.

In three of the five populations studied in 1982 seed capsules from naturally pollinated homostyle flowers contained significantly more seeds than those of naturally pollinated pin and thrum flowers (Wanstrow 1, Wyke, and Cloford). At the remaining homostyled population (Postlebury), homostyles did produce more seeds per capsule than pins, but the difference was not significant. Artificial pollination of pins and thrums led to an increase in seed capsule fertility at three populations (Wyke, Cloford, and Postlebury) only. Thus at Wanstrow 1 and Batcombe 1 pollinator availability did not limit seed set in pins and thrums, whereas it did in the other three populations, supporting the notion expressed above that there was spatial variation in pollinator availability.

That pollinator availability limited seed production in three relatively high frequency homostyle populations, but not in two low frequency homostyle populations, prompted us to study more populations in 1983 than in 1982, with a view to examining the plausibility of a negative relationship between good pollinator service and low homostyle frequency. The data collected in 1983 (table 2) do not confirm this relationship. However, they do show that over the entire study area (with the exception of Postlebury) seed capsules produced by naturally pollinated homostyle flowers contained significantly more seeds than those of naturally pollinated co-occuring outcrossing morphs. Moreover, artificial pollination led to a significant increase in seed number per capsule for pins and thrums. (In 1983 it was not possible to make this comparison at Cloford due to high levels of capsule predation.) Clearly, in 1983 homostyles were almost universally more fertile than the outcrossing morphs in terms of this index of fertility, and this must have been due to a paucity of pollinators. Furthermore, that artificial pollination lead to an increase in seed production in pins and thrums in all populations indicates that density dependent factors did not account for differences in seed capsule production among morphs in this instance.

The disparity in fertility between self-fertilising and outcrossing morphs was less in 1984 than 1983 (table 3). Although none of the populations studied in 1984 showed a significant response to artificial pollination of pin and thrum flowers, in terms of an increase in seed number per capsule, there was an obvious trend. At every population artificially pollinated flowers produced more seeds per capsule than naturally pollinated flowers. The probability of artificial pollination causing an increase in seed production in all ten cases by chance alone is approximately 0.001 which is highly significant. This observation supports the view that the abundance of pollinators limited seed set in pins and thrums in 1984, and that the effect was smaller than in 1982 and 1983. 


\section{(iii) Whole plant fertility}

Tables 1 and 2 also present the mean total seed output per plant for the morphs at the populations studied in 1982 and 1983 respectively. In 1982 homostyles produced significantly more seeds than co-occurring outcrossing morphs only at Cloford. At the remaining populations, homostyles did produce more seeds per plant, but the differences were not significant. In 1983 homostyles experienced a significantly higher fertility than co-occurring outcrossing morphs at all populations except two (Bruton and Postlebury); it is likely that the difference was nonsignificant at Bruton because pins produced many more flowers than homostyles (table 2).

Although it was not possible to obtain estimates of whole plant fertility in 1984 it is likely, in view of the seeds per capsule, and the capsule production data, that homostyles, pins, and thrums had essentially similar fertilities.

The whole plant fertility data reflect the temporal and spatial variation in pollinator availability inferred above. However, these data also show that in several populations where homostyles were present (Cloford in 1982, and Cogley, Wanstrow 2 , and Wanstrow 3 in 1983), pins produced significantly more seeds per plant than thrums, providing more support for the notion that superior female fertility of pins, when homostyles are present, prevents them from being eliminated as quickly as thrums.

\section{(iv) Sexual resource allocation}

(a) Pollen Production The two populations chosen for study were the two most likely to show evidence of a shift in sexual resources from male to female function in homostyles: at Wanstrow 1 homostyles were only 10 per cent of the population, whereas at Postlebury they were 80 per cent. Therefore at Wanstrow 1 homostyles would have a good chance at making a contribution to the outcrossing pollen pool, making a reallocation of resources from male to female function maladaptive. On the other hand, at Postlebury, homostyles would have only a poor chance of contributing to the outcrossing pollen pool due to the low frequency of pins, in which case a reallocation of sexual resources in favour of female function might be adaptive (Charlesworth and Charlesworth, 1981). Despite this expectation, thrums at Wanstrow 1 and homostyles from both populations produced comparable quantities of pollen in their anthers; at Wanstrow 1 thrums produced $2640 \pm 137$ pollen grains per anther, and homstyles produced $2448 \pm 124$. At
Postlebury homostyles produced $2472 \pm 197$ pollen grains per anther. There is thus no evidence to support the notion of a reduction in resources devoted to male function in homostyles. Ornduff (1979) observed far more pollen grains in the anthers of thrums in a population of $P$. vulgaris at Beddlestead in Berkshire, though he used a different counting procedure to the one adopted here. Fortunately though, the ratio of pin pollen production in pin and thrum anthers does not differ, whatever counting procedure is used (Piper in preparation) and as it is the ratios that we are concerned with here, differences in absolute values are not important.

(b) Ovule production Table 4 presents the mean number of ovules per ovary for the morphs at the populations studied in 1982. There were no significant differences among morphs, except at Wanstrow 1 where pin ovaries contained significantly fewer ovules than those of thrums and homostyles. Clearly, homostyles have not experienced a reallocation of resources in favour of female function.

Table 4 Mean number of ovules per ovary, with standard errors, for pins, thrums, and homostyles at the population studied in 1982

\begin{tabular}{llll}
\hline & \multicolumn{2}{l}{ Morph } & \\
\cline { 2 - 4 } Population & Pin & Thrum & Homostyle \\
\hline Batcombe 1 & $53 \cdot 2 \pm 1 \cdot 8$ & $56 \cdot 4 \pm 1 \cdot 6$ & - \\
Wanstrow 1 & $52 \cdot 8 \pm 1 \cdot 7^{*}$ & $61 \cdot 8 \pm 1 \cdot 8$ & $59 \cdot 8 \pm 2 \cdot 1$ \\
Wyke & $59 \cdot 0 \pm 1 \cdot 6$ & $56 \cdot 0 \pm 2 \cdot 2$ & $54 \cdot 3 \pm 1 \cdot 8$ \\
Cloford & $56 \cdot 0 \pm 2 \cdot 1$ & $53 \cdot 0 \pm 1 \cdot 9$ & $51 \cdot 0 \pm 1 \cdot 5$ \\
Postlebury & $50 \cdot 6 \pm 2 \cdot 2$ & - & $56 \cdot 0 \pm 1 \cdot 8$ \\
\hline
\end{tabular}

* Pin flowers produced fewer ovules per ovary than homostyles and thrums $(p<0 \cdot 01)$.

\section{(v) Inbreeding depression}

In 1984 the naturally pollinated outcrossing and self-fertilising morphs of $P$. vulgaris produced the same number of seed capsules per plant, and the same number of seeds per capsule. These seed capsules can be used to determine whether or not seeds produced by self-fertilisation are lighter (due to the expression of inbreeding depression) than those produced by pins and thrums.

Table 5 presents the mean seed mass of seeds produced by naturally pollinated pins, thrums, and homostyles, from three populations studied in 1984. Since there are only slight differences in seed number per capsule between pins and homostyles in any one population, we need not consider the 
Table 5 Mean weight of seeds, with standard errors, in capsules of pins, thrums, and homostyles in capsules collected from the populations studied in 1984. Numbers in brackets refer to the number of seed capsules weighed

\begin{tabular}{|c|c|c|c|}
\hline \multirow[b]{2}{*}{ Morph } & \multicolumn{3}{|l|}{ Population } \\
\hline & Cogley & Bruton & Postlebury \\
\hline $\begin{array}{l}\mathrm{H} \\
(n)\end{array}$ & $\begin{array}{c}0.018 \pm 0.0012 \\
(22)\end{array}$ & $\begin{array}{c}0 \cdot 019 \pm 0.0016 \\
(34)\end{array}$ & $\begin{array}{c}0.017 \pm 0.0014 \\
(26)\end{array}$ \\
\hline $\begin{array}{l}\mathrm{P} \\
(n)\end{array}$ & $\begin{array}{c}0.015 \pm 0.0012 \\
(29)\end{array}$ & $\begin{array}{c}0.018 \pm 0.0012 \\
(34)\end{array}$ & $\begin{array}{c}0.014 \pm 0.0012 \\
(26)\end{array}$ \\
\hline $\begin{array}{l}T \\
(n)\end{array}$ & $\begin{array}{c}0.018 \pm 0.0015 \\
(30)\end{array}$ & 一 & - \\
\hline
\end{tabular}

possibility of a negative correlation between seed mass and seed number (Adams, 1967; Werner and Platt, 1976; Wilbur, 1977; Primack, 1978; Stanton, 1984; Schaal and Leverich, 1984). At all three populations, mean seed mass did not differ among morphs, demonstrating that self-fertilisation in homostyles does not lead to reduced seed mass. Moreover, the fertility data indicate that homostyles do not abort any more progeny than pins and thrums. Support for this notion is provided by the following observations: at any one population the three morphs produced comparable numbers of ovules per flower, and in 1982, and 1983 at least, homostyle seed capsules were as fertile as artificially pollinated pin and thrum seed capsules. If homostyles experienced significant abortion, then one would expect homostyles to produce fewer seeds per capsule than artificially pollinated pin and thrum flowers, but inspection of tables 1 and 2 shows that this was not the case. These observations suggest that inbreeding depression is not expressed in the progeny of homostyles during seed production.

In addition, homostyles did not produce heavier seeds than pins and thrums. This observation suggests that a reallocation of resources from male to female function was not manifested in terms of an increase in seed mass in the selffertilising morph, providing further evidence for the notion that a reallocation of resources has not occurred in homostyles.

\section{DISCUSSION}

The results relating to flower production, sexual resource allocation, and inbreeding depression, demonstrate that the three morphs of $P$. vulgaris have essentially similar reproductive potential. These observations imply that differences observed in the fertility of self-fertilising and outcrossing morphs are attributable solely to fluctuations in the pollinator availability to pins and thrums. This view is supported by a comparison of the fertilities of seed capsules from naturally and artificially pollinated pin and thrum flowers. It has thus been demonstrated that variation in pollinator service in time and space can lead to low fertility in obligate outcrossers when compared to inbreeders (tables 1-3), which may favour the establishment of self-fertile individuals. That a reduction in pollinator availability can lead to sub-optimal seed set has been demonstrated before (Free, 1970; Levin and Anderson, 1970; Schemske et al., 1978; Barrett, 1980; Janzen et al., 1980; Schemske, 1980; Weller, 1980; Peterson et al., 1982). Similarly interspecific comparisons have shown that self-fertilising species are more seed fertile than related outcrossers because of reproductive assurance (Levin, 1972; Bawa, 1974; Ganders, 1975; Solbrig and Rollins, 1977). Reproductive assurance has, however, not been demonstrated before in populations containing both self-fertilising and outcrossing morphs. However, in view of fluctuations in the magnitude of the difference between the self-fertilising and outcrossing morphs observed during the study period it seems that the importance of this factor varies in time and space (tables 1-3). Moreover, the results presented reveal that an important assumption of population genetic models concerned with the evolution of self-fertilisation (Fisher, 1941; Crosby, 1949; Bodmer, 1960; Nagylaki, 1976; Charlesworth and Charlesworth, 1979; Wells, 1979; Lloyd, 1980; Lande and Schemske, 1985) is violated. Most assume that the relative fitness of the self-fertilising and outcrossing morphs is constant. Clearly, the fertility component of fitness of self-fertilising and outcrossing forms in the situation described does vary, thus the applicability of these models to the evolution of homostyly is not entirely clear, and so they cannot be used as they stand to predict the fate of homostyles, i.e. whether or not they will go to fixation, or achieve some intermediate equilibrium frequency.

Although the proximate cause of differences in the fertility of outcrossing and self-fertilising morphs of $P$. vulgaris was identified as restricted pollinator availability, the pollinator service to primroses could not be observed directly, as pollinator visits to primroses are rarely observed (Woodell, 1960).

Numerous studies have shown that ecological factors can affect pollinator service to plants (Willis and Burkill, 1895; 1903; Wilson, 1929; Hagerup, 1950; 1951; Hiyamoto, 1960; Eisikowitch 
and Galil, 1971; Heinrich, 1972; Proctor and Yeo, 1973; Schemske, 1977), and it is likely that pollinator service to pins and thrums varied in this study due to the prevailing climatic conditions in the study area during primrose flowering. Fig. 2 presents the mean half monthly rainfall for four months pooled from seven weather stations in the study area, and mean daily temperatures for the same months from the same stations (data provided by the Wessex Water Authority). By inspection, it can be seen that when rainfall is low in the peak period of primrose flowering (April to May) seed set of pins and thrums is relatively good (1982 and 1984), but when rainfall is high during this period (1983) the fertility appears to be negatively correlated with high rainfall, which presumably deters pollinators. The similarities in mean daily temperature during the three years of study indicates that this factor had no influence on pollinator service.

In situations where pollinator availability limits seed set, it is to be expected that self-incompatible individuals might produce a large floral display in order to attract pollinators, despite the fact that resources to mature seeds in all capsules might not be available. However, in a self-fertilising species there would be no advantage in producing a conspicuous floral display, as pollinator visits are not required to ensure seed set. Thus one might expect a self-fertilising morph to produce fewer, or smaller, flowers than co-occurring outcrossing morphs. No attempt was made here to assess differences in flower size among morphs, but it is clear that gross differences do not exist. However the data collected suggests that there is no tendency for homostyles to produce fewer flowers than pins and thrums. Hence homostyles were not seen to "exercise" any form of reproductive economy. Two hypotheses can be put forward to account for this observation. Firstly it might be that sufficient time has not elapsed for this trait to have evolved in homostyles. Alternatively the production of many flowers may be advantageous to the homostyles, for example; if a showy floral display attracts many pollinators, then this could improve the male fitness of the homostyles through pollen export.

A shift in resources from male to female function was not observed in the homostyles. This is surprising as Charlesworth and Charlesworth (1981) demonstrated theoretically that a shift in resources from male to female function should accompany the evolution of self-fertilisation. That this reallocation has not been observed may be because homostyles have not been around long enough. This proposal is supported by the observation that in Primula scotica, a member of the Primula genus where homostyly has become fixed, reallocation of sexual resources in favour of female function has been observed (Piper unpublished).

The fertility data presented above have demonstrated that reproductive assurance has the poten-
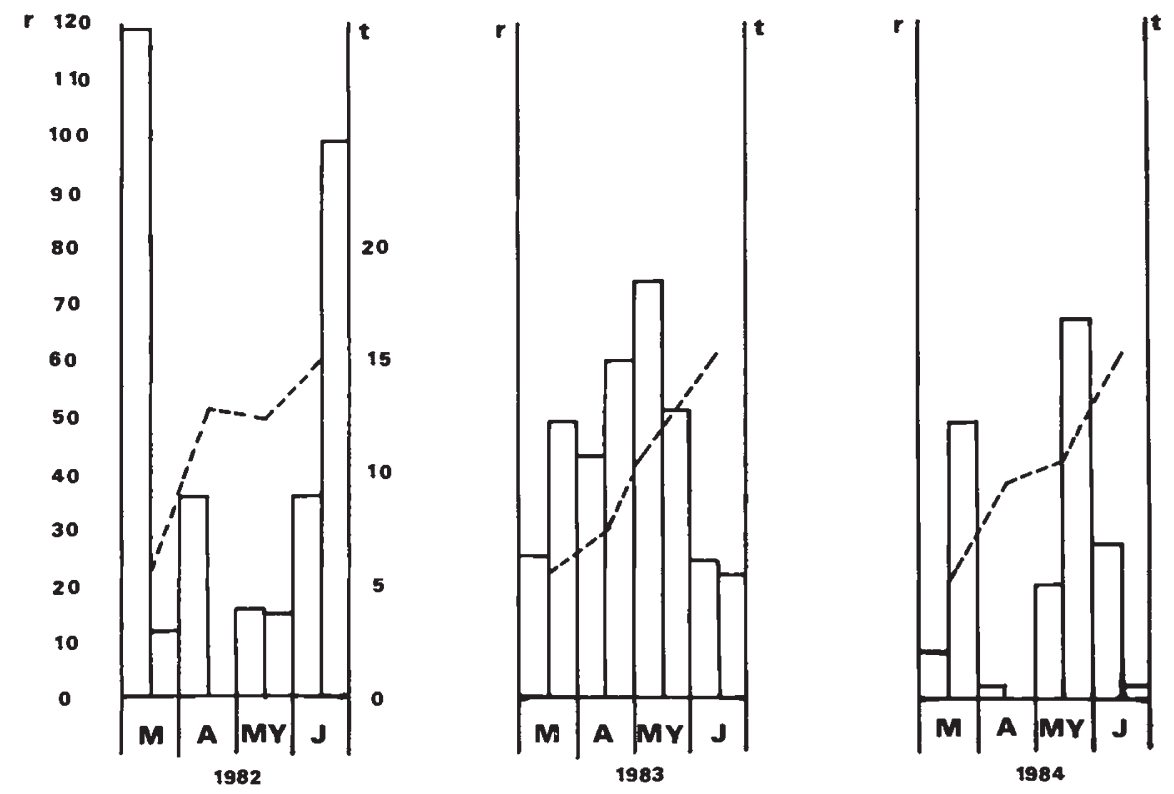

Figure 2 Half monthly rainfall in millimetres (histogram) and mean daily temperatures in ${ }^{\circ} \mathrm{C}$ (dotted line) for the study area in March, April, May, and June in 1982, 1983, and 1984. (Data provided by the Wessex Water Authority.) 
tial to play an important role in the evolution of self-fertilisation. It has also provided an explanation of another phenomenon observed in Somerset populations of $P$. vulgaris. The population surveys of Crosby (1949), and Curtis and Curtis (1985) on Somerset populations of $P$. vulgaris show that thrums are eliminated prior to pins when homostyles are increasing in frequency. This relatively rapid elimination of thrums has been referred to as "thrum decline" (Crosby, 1949).

This study showed that, in several populations where pins, thrums, and homostyles co-occurred pins were more seed fertile than thrums (tables 1 and 2.) This disparity can be accounted for by the compatibility relationships of the various morphs. Homostyles and thrums produce the same type of pollen, and so compete for access to pin ovules. Homostyles also have stigmas with the compatibility relationships of pins, but because they are almost exclusively self-fertilising, the quantity of thrum pollen that fertilises homostyles is negligible. Consequently, as homostyle frequency increases the male fertility of thrums declines. The male fertility of pins also declines as thrums become relatively less abundant, but their female fertility (relative to thrums) does not, because the frequency of thrum type pollen donors (thrums and homostyles) does not decline. The same is not true for thrums. As homostyles increase in frequency, pins decrease, and as a result there is less pollen available for the fertilisation of thrums. Therefore, an additional factor causing the elimination of thrums is their poorer female fertility (relative to pins) in the presence of homostyles.

Finally, and perhaps most importantly, this study demonstrates how a component of fitness (in this case fertility) can vary from population to population, and from season to season. In view of this it can be seen that conclusions drawn from a few populations observed over a short time span must be treated with extreme caution. Without long term studies, it will be difficult to interpret models that attempt to chart the evolution of plant breeding systems.

Acknowledgements We thank Chris and Jill Curtis for providing accommodation during the field work phase of this project, and for furnishing us with their seemingly inexaustable local knowledge. This research was sponsored by an S.E.R.C. Quota award to J.G.P.

\section{REFERENCES}

ADAMS, M. U. 1967. Bases of yield component compensation in crop plants with special reference to the field bean, Phaseolus vulgaris. Crop Sci. 7, 505-510.
BAKER, H. G. 1959. Reproductive methods as factors in speciation in flowering plants. Cold Spr. Harb. Symp. Quant. Biol., 24, 177-190.

BAKER, H. G. 1965. Characteristics and modes of origin of weeds. In The genetics of colonising species. ed. H. G. Baker and G. L. Stebbins. Academic Press, New York.

BARRETT, S. C. H. 1980. Sexual reproduction in Eichhornia crassipes (water hyacinth). I. Fertility of clones from diverse regions. J. Appl. Ecol., 17, 101-112.

BATESON, W. AND GREGORY, R. P. 1905. On the inheritance of heterostylism in Primula. Proc. R. Soc. Lond. B., Biol. Sci. 76, 581-586.

BAWA, K. S. 1974. Breeding systems of tree species of a lowland tropical community. Evolution., 28, 85-95.

BODMER, W. F. 1960. The genetics of homostyly in populations of Primula vulgaris. Phil. Trans. R. Soc. Lond. B. Biol. Sci., 242, 517-549.

BODMER, W. F. 1984. Sex and generations of Primroses. Nature., 310,731 .

BRINK, R. A. AND COOPER, D. C. 1947. The endosperm in seed development. Bot. Rev., 13, 426-542.

CALAHAN, C. N. AND GLIDDON, C. 1985. Genetic neighbourhood sizes in Primula vulgaris. Heredity, 54, 65-70.

CHARLESWORTH, D. AND CHARLESWORTH B. 1979. The maintenance and bread down of distyly. Am. Nat., 114, 499-513.

CHARlesworth, D. AND Charlesworth, B. 1981. Allocation of resources to male and female function in hermaphrodites. Biol. J. Linn. Soc., 14, 57-74.

CLAPHAM, A. R., TUTIN, R. G. AND WARBURG, E. F. 1962. Flora of the British Isles. 2nd edition. Cambridge University Press.

COlOSI, J. C. AND CAVERS, P. B. 1984. Pollination affects percent biomass allocated to reproduction in Silene vulgaris (Bladder Campion). Am. Nat., 124, 299-306.

CROSBY, J. L. 1949. Selection of an unfavourable gene complex. Evolution, 3, 121-230.

CROSBY, J. L. 1959. Outcrossing on homostyle primroses. Heredity, 13, 127-131.

CROSBY, J. L. 1960. The use of electronic computations in the study of random fluctuations in rapidly evolving populations. Phil. Trans. R. Soc. Lond. B. Biol. Sci., 242, 551-572.

CURTIS, J. AND CURTIS, C. F. 1985. Homostyle primroses revisited: variation in time and space. Heredity, 54, 227-234.

DARWIN, C. 1876. Effects of cross and self fertilisation in the vegetable kingdom. London. John Murray.

DARWIN, C. 1877. The different forms of flowers on plants of the same species. London. John Murray.

DOWRICK, V. P. J. 1956. Heterostyly and homostyly in Primula obconica. Heredity, 10, 219-236.

EISIKOWITCH, D. AND GALIL, J. 1971. Effect of wind on the pollination of Pancratium maritimum L. (Amaryllidaceae) by Hawkmoths (Lepidoptera: Sphingidae). J. Anim. Ecol., 40, 673-678.

ERNST, A. 1936a. Heterostylie-forschung. Versuche zur genetischen Analyse eines Organisationsund "Anpassungs" merkmales. Z. Indukt. Abstammings-vererbungsl, 71, 156-230.

ERNST, A. 1936b. Weitere Untersuchungen zur Phananalyse zum Fertilitatsproblem und zur Genetik heterostyler Primein. II. Primula hortensis Wettstein. Arch Julius KlausStift Vererbungsforsch. Soziaianthropol. Rassenhyg., ii, 1280.

FISHER, R. A. 1941. Average excess and average effect of a gene substitution. Ann. Eugen., 11, 53-63.

FRANKLIN, E. C. 1972. Genetic load in loblolly pine. Am. Nat. $106,262-265$.

FREE, J. B. 1970. Insect pollination of crops. Academic Press, New York. 
GANDERS, F. R. 1975. Heterostyly, homostyly and fecundity in Amsinkia spectabilis (Boraginaceae). Madrono, 23, 56-62.

GHISELIN, M. T. 1969. The evolution of hermaphroditsm among animals. Quart. Rev. Biol., 44, 189-208.

GHISELIN, M. T. 1974. The economy of nature and the evolution of sex. University of California Press.

HAGERUP, O. 1932. On the pollination in the extremely hot air at Timbuktu. Dansk. Bot. Ark., 8, 1-20.

hagerup, D. 1950. Rain Pollination. D. Kgl. Danske. Vidensk Selsk. Biol. Medd., 17, 1-10.

HAGERUP, O. 1951. Pollination in the Faroes-in spite of rain and poverty in insects. $D . \mathrm{Kgl}$. Danske. Vidensk. Selsk. Biol. Medd., 18, 1-47.

HEINRICH, B. 1972. Temperature regulation in the bumblebee Bombus vagans: a field study. Science, 175, 185-187.

JAIN, S. K. 1976. The evolution of inbreeding in plants. Ann. Rev. Ecol. Syst., 7, 469-495.

JAMES, S. H. 1979. Chromosome numbers and genetic systems in the trigger plants of Western Australia (Styldium: Stylidaea). Aust. J. Bot., 27, 17-25.

JANZEN, D. H., DEVRIES, P., GLADSTONE, D. E., HIGGINS, M. L. AND LEWINSOHN, T. M. 1980. Self and cross pollination of Eucyclia cordigera (Orchidaceae) in Santa Rosa National Park, Costa Rica. Biotropica, 12, 72-74.

KOSKI, v. 1971. Embryonic lethals of Picea abies, and Pinus sylvestris. Comm. Inst. For. Fenn., 75, 1-30.

LANDE, R. AND SCHEMSKE, D. 1985. Evolution of self fertilisation and inbreeding depression in plants. I. Genetic models. Evolution. 39, 24-40.

LEVIN, D. A. 1972. Competition for pollinator service: a stimulus for the evolution of autogamy. Evolution, 26, 668-674.

LEVIN, D. A. AND ANDERSON, W. w. 1970. Competition for pollinators between simultaneously flowering species. $A m$. Nat., 104, 455-467.

LINK, A. J. 1961. The morphological development of the seed of Pisum sativum var Alaska. Phytomorphology, 11, 79-83.

LLOYD, D. G. 1979. Some selective forces affecting the frequency of self fertilisation in angiosperms. Am. Nat., 113, 67-79.

LLOYD, D. G. 1980. Demographic factors and mating patterns in angiosperms. In Demography and evolution in plant populations. ed. O. T. Solbrig, Blackwell Scientific Publications.

MIYAMOTO, S. 1960. Observations on the behaviour of Bombus diversus Smith (Biological studies on Japanese bees 13) Insectes Sociaux, 7, 39-56.

NAGYLAKI, T. 1976. A model for the evolution of self fertilisation and vegetative reproduction. $J$. Theor. Biol. 58, 55-58.

ornduff, R. 1979. Pollen flow in a population of Primula vulgaris Huds. Bot. J. Linn. Soc., 78, 1-10.

PETERSON, C., BROWN, J. H. AND KODRIC-BROWN, A. 1982. An experimental study of floral display and fruit set in Chilopsis linearis. (Bignoniaceae). Oecologia, 55, 7-11.

PIPER, J. G. 1985. Breeding system evolution in Primula vulgaris. D.Phil. Thesis, Univ. of Sussex.

PIPER, J. G., CHARLESWORTH, B. AND CHARLESWORTH, D. 1984. A high rate of self-fertilisation and increased fertility in homostyle primroses. Nature, 310, 50-51.
PRIMACK, R. B. 1978. Regulation of seed yield in Plantago, $J$. Ecol., 66, 835-847.

PROCTOR, M. C. F. AND YEO, P. F. 1973. The pollination of flowers. Collins New Naturalist, London.

ROWLANDS, D. G. 196a Fertility studies in field bean (Vicea faba L). I. Cross and self fertilisation. Heredity, 15, 161173.

SAYERS, E. R. AND MURPHY, R. P. 1966. Seed set in Alfalfa as related to pollen tube growth, fertilisation frequency, and post fertilisation ovule abortion. Crop Sci. 6, 365-368.

SCHAAL, B. A. AND LEVERICH, w. J. 1984. Age-specific fitness components in plants: genotype and phenotype. In: Population Biology and Evolution. Ed. K. Wohrmann, and V. Loeschke. Springer-Verlag.

SCHEMSKE, D. W. 1977. Flowering phenology and seed set in Claytonia verginica (Pertulaceae). Bull. Torry. Bot. Club, 104, 254-263.

SCHEMSKE, D. W. 1980. Evolution of floral display in the orchid Brassavola nodosa. Evolution. 34, 489-493.

SCHEMSKE, D. W., WILLSON, M. F., MELAMPY, M. N., MILLER, C. J., VER NER, L., SCHEMSKE, K. M. AND BEST, L. B. 1978. Flowering ecology of some spring woodland herbs. Ecology, 59, 351-366.

SOKAL, R. R. AND ROHLF, F. J. 1981. Biometry: the principles and practice of statistics in biological research. 2 nd edition, W. H. Freeman. San Francisco.

SOlBRIG, O. T. AND ROLliNS, R. C. 1977. The evolution of autogamy in species of the mustard genus Leavenworthia. Evolution, 31, 265-281.

SORENSON, F. 1969. Embryonic genetic load in douglas fir Pseudotsuga menziesii var menziesii. Am. Nat., 103, 389398.

STANTON, M. L. 1984. Developmental and genetic sources of seed weight variation in Raphanus raphinastrum L (Brassicaceae). Am. J. Bot., 71, 1090-1098.

WEller, S. G. 1980. Pollen flow and fecundity in populations of Lithospermum carolinense. Am. J. Bot., 67, 1334-1341.

WELLS, H. 1979. Self-fertilisation advantageous or deleterious? Evolution, 33, 252-255.

WERNER, P. A. AND PLATT, W. J. 1976. Ecological relatiónships of co-occurring golden rods (Solidago: compositae). Am. Nat., 110, 959-971.

Wilbur, H. M. 1977. Propagule size, number and dispersion pattern in Ambystoma, and Asciepias. Am. Nat., 111, 4368.

WILlis, J. C. AND BURKILL, H. 1895. Flowers and insects in Great Britain. Part 1. Ann. Bot., 9, 227-273.

WILlis, J. C. AND BURKILl, I. H. 1903. Flowers and insects in Great Britain. Part 2. Observations on the natural orders Dipsaceae, Plumbaginaceae, Compositae, Umbelliferae, and Cornaceae, made in the Colva Mountains. Ann. Bot., 17, 313-349.

WILSON, G. F. 1929. Pollination of hardy fruits: insect visitors to fruit blossoms. Ann. Appl. Biol., 16, 602-629.

WOOdELL, S. R. J. 1960 . What pollinates primulas? New Scientist, $8,568-571$. 